Archived version from NCDOCKS Institutional Repository http://libres.uncg.edu/ir/asu/

\title{
Appalachỉan
}

B O O N E, N O R T H C A R O L I N A

\section{Regional Resilience: Opportunities, Challenges And Policy Messages From Western North Carolina}

\author{
By: Susan Slocum and Carol Kline
}

\begin{abstract}
This paper explores resiliency theory by assessing the ability of communities to adapt and recover economically and socially after a natural disaster. Community resiliency describes the capacity of finding a new equilibrium that is strengthened from change. Resilience can be seen as a strategy to facilitate recovery after a trauma and can be used as a preventative measure to avoid undesired outcomes. Through a qualitative assessment of the HandMade in America programme in three rural communities in Western North Carolina, this paper draws attention to the facilitation of community capital, resulting in social and political networks that allowed these towns to rely on increases in tourism to rebound from the 2004 hurricanes season.
\end{abstract}

Slocum S, Kline C. Regional resilience: opportunities, challenges and policy messages from Western North Carolina. Anatolia: An International Journal of Tourism \& Hospitality Research. 2014;25(3):403-416. doi:10.1080/13032917.2014.888673. Publisher version of record available at: https://www.tandfonline.com/doi/ full/10.1080/13032917.2014.888673 


\title{
Regional resilience: opportunities, challenges and policy messages from Western North Carolina
}

\author{
Susan Slocum ${ }^{\mathrm{a} *}$ and Carol Kline ${ }^{\mathrm{b}}$ \\ ${ }^{a}$ Department of Applied Economics, Utah State University, 4835 Old Main Hill, Logan, UT 84322, \\ USA; ${ }^{b}$ Department of Recreation and Leisure Studies, Center for Sustainable Tourism, \\ East Carolina University, RW Rivers 208, Greenville, NC 27858-4354, USA
}

\begin{abstract}
This paper explores resiliency theory by assessing the ability of communities to adapt and recover economically and socially after a natural disaster. Community resiliency describes the capacity of finding a new equilibrium that is strengthened from change. Resilience can be seen as a strategy to facilitate recovery after a trauma and can be used as a preventative measure to avoid undesired outcomes. Through a qualitative assessment of the HandMade in America programme in three rural communities in Western North Carolina, this paper draws attention to the facilitation of community capital, resulting in social and political networks that allowed these towns to rely on increases in tourism to rebound from the 2004 hurricanes season.
\end{abstract}

Keywords: resilience; natural disaster; sustainability; North Carolina; crafts

\section{Introduction}

Communities are influenced by external forces which fall outside the control of regional or national regulatory structures and can be accelerated through globalized processes (Church, 2004). These forces include changing patterns of industrial development which influence rural spatial patterns and cause stress on communities and traditional industries. Many theorists agree that over-dependence on monofunctional agricultural production leads to economic dependency and increasing poverty (Chaskin, 2008; Rigg, 2006). Agriculture no longer forms the backbone for rural development; instead rural spaces are characterized by complex, multidimensional and hybrid development (Saxena, Clark, Oliver, \& Ilbery, 2007). Once the mainstay of rural development, agriculture is being replaced by emerging industries such as tourism.

Multifaceted development patterns influence migration, decrease the availability of capital to rural areas and create a larger command and control regulatory system that governs rural spaces. In addition, there is a constant struggle between the inherited natural landscapes, often derived from obsolete practices which are no longer viable, and pressures to conform to certain economic and social trends (Piorr, 2003). Outward migration from rural areas is viewed as a negative impact that diminishes human capital, and greying communities find it increasingly difficult to incorporate modern technologies and progressive ideas into land-use planning (Pretty, 2002). Decreasing capital forces community members into the poverty trap where they struggle to raise sufficient capital and income for survival, leaving little time or resources to diversify economically. Making

*Corresponding author. Current address: Department of Tourism and Event Management, George Mason University, 10900 University Blvd. MSN 4E5, Manassas, VA 20110, USA. Email: sslocum@gmu.edu 
right and wrong development decisions are becoming more difficult and complex. Therefore, an understanding of community capacity, through the theoretical construct of community resilience, provides new insight into community evolution, adaption to change and the dynamisms of global environments.

Seldom approached in tourism analysis, resilience theory is a vital tool in the sustainability assessment tool box (Wilson, 2010) and has gained recent recognition in academic articles addressing crises management, land use policy, social capacity, and agriculture. Using data from three rural North Carolina communities affected by the 2004 hurricane season, this case study argues that through the HandMade in America programme, community resiliency was instilled that supported the economic and social recovery efforts. In particular, the development of the craft industry and the Small Town Program that helped revitalize a number of historic buildings and parks assisted these three communities to rely on the increase in tourism to rebound from the natural disasters that affected them.

\section{Literature review}

Resilience theory was originally used to describe the ability of a system to return to equilibrium after a trauma (Norris, Stevens, Pfefferbaum, Wyche, \& Pfefferbaum, 2008) and has been used to assess the capabilities of environments (Gunderson, 2000), individuals (Boss, 2001), and families (Landau, 2007) facing multiple transitions and stresses. However, its use in the assessment of communities is relatively new in academic literature. Community resilience describes the ability of a community to adapt to change and, rather than returning to a previous steady state, to find a new equilibrium that is strengthened from the experience (Matthews \& Selman, 2006). As resilience can be explained as "a process linking a set of adaptive capacities to a positive trajectory of functioning and adaptation after a disturbance" (Norris et al., 2008, p. 130), the definition of community resilience is the existence, development, and engagement of community resources by community members to thrive in an environment characterized by change, uncertainty, unpredictability, and surprise (Magis, 2010).

Resilience should be viewed as a positive adaptive response to adversity where actors can draw on natural, human, cultural, social, financial, built, and political capital to negotiate change (Ahmed, Seedat, van Niekerk, \& Bulbulia, 2004). While resilience can be seen as a strategy to facilitate recovery after a traumatic event, it can also be used as a preventative measure to avoid poor outcomes. Therefore, resilience is not about controlling conditions, but developing a community's ability to respond to change (Ahmed et al., 2004). It includes community learning and the ability of a community to take responsibility and control over their development pathways.

Resiliency provides opportunities for communities to adopt strategies that complement their particular environments and reinforces feedback loops resulting in socially preferred outcomes (Cutter et al., 2008). Resilience allows communities to develop multi-industry economies and reduces dependency on global agricultural markets. In turn, this increases employment and business opportunities, reduces poverty and increases the quality of life for residents (Pretty, 2002). It can increase local business ownership and create new markets and technologies for local production, decreasing economic leakages (Lyson, 2004) while empowering families in non-traditional industries (Rigg, 2006). Resilience decreases reliance on outside agencies, including the need for subsidies, increases autonomy and provides avenues for new learning and knowledge exchange between groups (Goss \& Burch, 2001).

There are a number of challenges in implementing the resilience model. Resilience requires strong leadership and may compel members to develop new skill sets to become 
effective leaders and to facilitate cooperation between different groups (Wilson, 2010). Sometimes a major shift in the power structure may be required. In addition, capitals are often intertwined, which can result in unintended side effects as elements of the system are changed. Modernization practices require a new perspective on the use of resources, technologies, business models and can alter historic traditions (Matthews \& Selman, 2006). Therefore, communities need a forward vision, learning how to adapt to changing environments, working within dynamic markets rather than seeking immediate results.

Waller (2001) argues that resilience should be viewed as adaptability and that stability, or the failure to change, is a lack of resilience. Communities should move beyond "stability" models and towards "symbiotic" models of development (Kelly \& Bliss, 2009).

Table 1 explains the eight dimensions that contribute to the community reliance process. Using data from a number of communities in North Carolina, this paper introduces resilience theory as a means to understand and assess individual communities' ability to forge through the changing nature of tourism as a development tool.

\section{Applications of resilience theory}

Resilience theory was first introduced through the psychology and sociology disciplines as a means to describe the human response to adversity and the coping mechanism utilized for recovery (Sonn \& Fisher, 1998). Cottrell (1976) approached community competence as a means to provide opportunities that allow groups within a community to cope with their problems, and Elsass (1992) expanded by challenging that oppressed communities faced the inability to develop the social and psychological support structures that allows for involvement and the development of activities and social relationships.

Community resilience was first utilized to gauge a region's response to varying natural resource uses and stewardships. Piorr (2003) recognized that landscape practices (often based on agro-landscapes) create the character, distinctiveness and ecological diversity that derive the cultural landscape. Matthews and Selman (2006) argue that it is these economic activities and landscape practices that drive change, and refer to "vicious circles" as being "characterized by obsolescence of traditional production, processing and marketing methods, and which could result either in extreme intensification or virtual abandonment" (p. 200). They choose to endorse "virtuous circles" which promote place-qualities and "a 'landscape premium' emerges in which people benefit economically from doing things that enhance multiple landscape functions, which, in turn, supply further services that enhance quality of life and economic opportunity" (p. 201). Resilience only plays a role in creating virtuous circles if a community is in a desired state of attraction, but is viewed as a disadvantage if in flux. Varghese, Krogman, Beckley, and Nadeau (2006) stress the importance of community resilience because it more directly addresses entitlements and how the human use of resources is distributed through institutions. Varghese et al. (2006) challenge Matthews and Selman by stating that "community resiliency refers to how communities adapt at times of vulnerability when altered property rights or access to resources threaten the continuation of current levels of wellbeing" (p. 508).

Atterton (2007) discovered mixed results in assessing community resilience and responsiveness to change. In a study of businesses in Scotland, she found that tight social networks in remote areas may hamper the economic growth of a region. It appeared that the influx of migration increased a broader spectrum of community ties that enhanced the success of business development, whereas tightly structured local ties resulted in "a lack of openness to different information through extra-local weak ties, a high degree of inflexibility, a lack of adaptability and a situation where social norms and obligations may 
Table 1 . The eight community resilience dimensions.

\begin{tabular}{|c|c|c|}
\hline Dimensions & Justification & Associated metrics \\
\hline $\begin{array}{l}\text { Utilization of } \\
\text { community } \\
\text { resources }\end{array}$ & $\begin{array}{l}\text { Engaging natural, human, } \\
\text { cultural, social, financial, } \\
\text { built, and political capital }\end{array}$ & $\begin{array}{l}\text { (1) The understanding of the opportunities and } \\
\text { limitations of the natural environment } \\
\text { surrounding the community } \\
\text { (2) The extent community leaders are networked } \\
\text { with resources outside the community } \\
\text { (3) The extent community members believe that } \\
\text { change is inevitable and that the community } \\
\text { can adapt successfully }\end{array}$ \\
\hline $\begin{array}{l}\text { Development of } \\
\text { community } \\
\text { resources }\end{array}$ & $\begin{array}{l}\text { Requires action taken, not } \\
\text { simply the capacity to act }\end{array}$ & $\begin{array}{l}\text { (1) The new kinds of business and employment } \\
\text { opportunities developed over the last } 10 \text { years } \\
\text { (2) The preparedness of youth with developed } \\
\text { work habits and becoming involved citizens, } \\
\text { empowered to take action and advocate ideas } \\
\text { and concerns } \\
\text { (3) The extent to which communities affected by } \\
\text { change try new ways of doing things }\end{array}$ \\
\hline $\begin{array}{l}\text { Engagement } \\
\text { of community } \\
\text { resources }\end{array}$ & $\begin{array}{l}\text { Objectives that develop } \\
\text { community resilience, } \\
\text { and generates additional } \\
\text { resources and capacity }\end{array}$ & $\begin{array}{l}\text { (1) The effectiveness of community government } \\
\text { in dealing with important problems facing the } \\
\text { community } \\
\text { (2) The extent to which community organizations } \\
\text { contribute leadership and volunteers to } \\
\text { community endeavours } \\
\text { (3) The extent to which communities generate } \\
\text { ideas to address change that are new and that } \\
\text { involve recombining resources in different } \\
\text { and creative ways }\end{array}$ \\
\hline Active agents & $\begin{array}{l}\text { Influencing its well-being } \\
\text { and taking a leadership } \\
\text { role }\end{array}$ & $\begin{array}{l}\text { (1) Community members' belief in their ability to } \\
\text { affect the community's well-being } \\
\text { (2) Community members' involvement in various } \\
\text { groups and events } \\
\text { (3) Community's self-reliance in addressing } \\
\text { major issues and changes affecting the } \\
\text { community }\end{array}$ \\
\hline $\begin{array}{l}\text { Collective } \\
\text { action }\end{array}$ & $\begin{array}{l}\text { Diverse and autonomous } \\
\text { groups work together, } \\
\text { know what organizations } \\
\text { and people are important, } \\
\text { and how to accomplish } \\
\text { their objective }\end{array}$ & $\begin{array}{l}\text { (1) The extent to which community leaders } \\
\text { facilitate collaboration between groups to } \\
\text { work on community objectives } \\
\text { (2) The extent to which community decision- } \\
\text { making processes engage diverse perspectives } \\
\text { and reflect cultural differences } \\
\text { (3) The extent to which people from diverse } \\
\text { groups share supports, resources, knowledge, } \\
\text { and expertise when confronted with change }\end{array}$ \\
\hline Strategic action & $\begin{array}{l}\text { Developed through } \\
\text { conscious deliberation, } \\
\text { planning, implemen- } \\
\text { tation, and learning }\end{array}$ & $\begin{array}{l}\text { (1) The extent to which information on } \\
\text { community resources is used in planning } \\
\text { community endeavours } \\
\text { (2) The extent to which local planning processes } \\
\text { generate a communitywide commitment to a } \\
\text { common future } \\
\text { (3) The extent to which community members look } \\
\text { outside the community to find resources to } \\
\text { support its endeavours }\end{array}$ \\
\hline
\end{tabular}




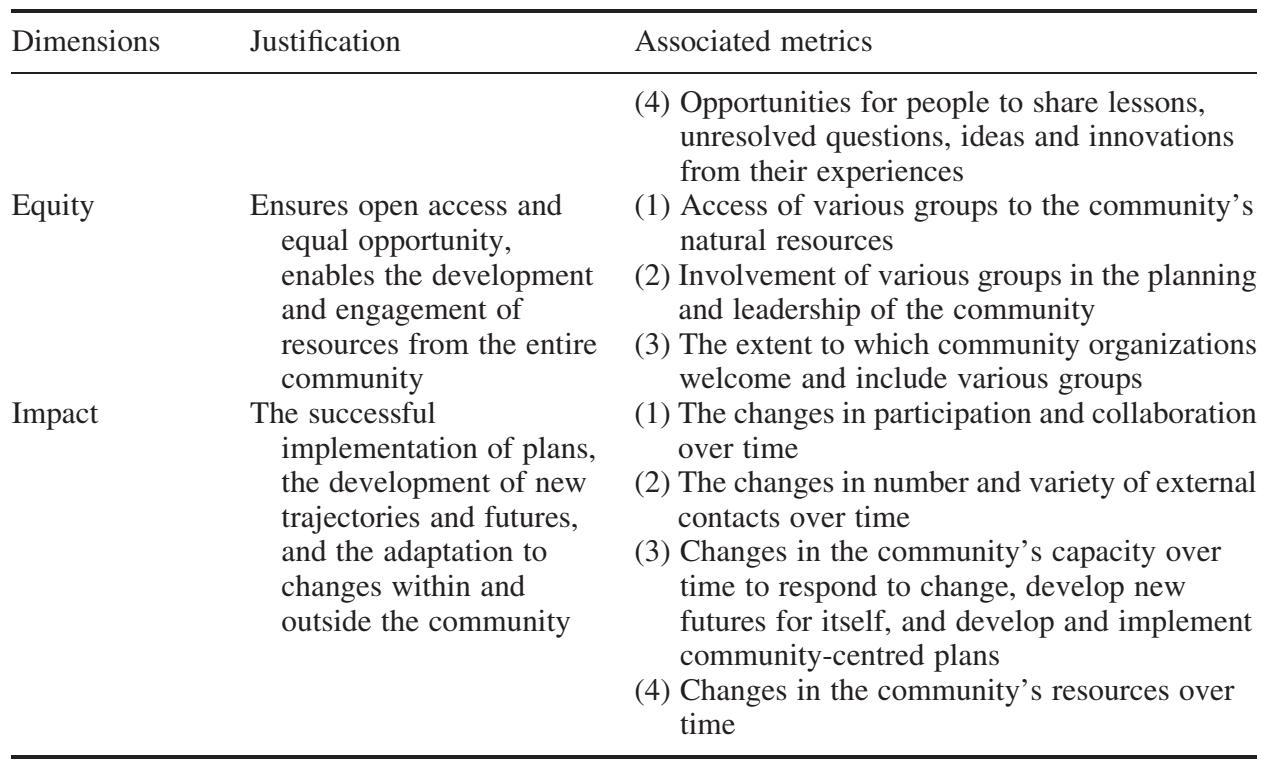

Source: Adapted from Magis (2010).

override economic arguments" (p. 240). Shava, Krasny, Tidball, and Zazu (2010) echo these sentiment through a study of rural to urban migration and resettlement in South Africa, claiming that the infusion of multiethnic values and practices combined with a widespread network of social ties has increased community resilience in the face of globalization and economic struggle. Both authors admit that a supportive policy structure should be in place to encourage traditional values while bringing knowledge into the communities facing change.

Community resilience has only recently been applied to tourism-based communities. Initially, resilience was used to describe a tourism industry's response to outside threats. Pearce (2001) used the concept to assess the ability of the New Zealand tourism industry to adapt to the Asian financial crises through the expansion of the newly formed New Zealand Tourism Board. Zeng, Carter, and De Lacy (2005) claim that the natural resilience of tourism as an economic sector helped mitigate the effect SARS had on tourism in China and that through increased destination marketing and the reassessment of destination image, post-crises recovery was enhanced. Calgaro and Lloyd (2008) developed a model to assess which socio-political and environmental conditions most negatively affected the recovery of Khao Lak, Thailand, after the tsunami and which attributes could contribute towards the long-term resilience of similar communities. They found that reliance on outside large-scale tourism businesses and limited diversification and seasonality of the tourism product were the main areas of vulnerability.

Recent articles have approached sustainable tourism from a resiliency perspective. Tyrrell and Johnston (2007) defined resilience as "the dynamics of community environmental quality (or character) subject to visitor-induced degradation" (p. 17) and concluded that different sizes, types and levels of infrastructure development play a key role. Maroudas, Kyriakaki, and Gouvis (2004), in an attempt to reduce negative impacts of seasonal mountain tourism, determine that clear policy guidelines that incorporate community involvement can help reduce these negative impacts by generating new avenues to increase the tourism season and 
create a more even pattern of visitation. They conclude by saying, "The cohesion and welfare of the local community and the existence of networks between business units of the community, nongovernmental organizations and research centers are essential for endogenous and sustainable tourism development" (p. 17). Scheyvens and Momsen (2008) use the terms "resilience" and "social capital" interchangeable when looking at the social constructions of small island states, but conclude that social cohesion and cultural traditions place small island states in a position to capitalize on certain forms of tourism development. Hamzah and Hampton (2013) assess the exogenous factors threatening equilibrium in smallscale tourism development in Malaysia and show that community resiliency has led to nonlinear change, rather than conventional resort development, and a community led effort to reduce mass tourism policies at the national and regional levels.

It is important to note that the tourism literature has provided a number of examples on natural resource resilience (Lambert, Hunter, Pierce, \& MacLeoda, 2010; Turton, 2005) or industry resilience (Coghlan \& Prideaux, 2009; Henderson \& Smith, 2009), but community resilience as a theoretical concept is still in its infancy in tourism. Therefore, this paper addresses community resilience through the development of the HandMade programme in rural North Carolina as a means to examine a theoretical framework that encourages and supports tourism as an economic diversification strategy for communities coping with change. Exploring Magis' eight dimensions of resilience, this paper argues that community resilience aided Western North Carolina in its recovery efforts after a particularly harsh hurricane season.

\section{Research sites}

The Appalachian Region of the USA has a history of underdevelopment and has frequently been classified as a "region apart", plagued with "profound economic and social problems" (Appalachian Regional Commission, 2010, p. 1), with one in three residents living in poverty. The mid-1990s showed Western North Carolina facing serious demographic and economic changes in their local communities. The tobacco industry, on which many residents relied, has seen extensive competition from newly emerging markets (China, India, and Brazil). This lack of economic opportunity resulted in a migration shift, with natives moving out, non-natives moving in, increased land development, traditional industrial decline, and job losses. Therefore, new sectors were investigated as a means to bring growth to the shrinking economy.

\section{HandMade in America}

HandMade in America was started as a regionally focused non-profit organization committed to celebrating the craft industry and the craft heritage of the region. In 1995, HandMade released its first guidebook "The Craft Heritage Trails of Western North Carolina". This publication was designed to inspire tourists to the rural mountain communities to experience the traditional crafts, the rich heritage and the unique sense of place found in rural North Carolina. Through a series of community meetings involving the arts community, educators, economic development agencies and businesses, farmers, elected officials, faith-based, and other community leaders, the feasibility of a regional homegrown craft-based initiative was designed to increase revenue to artists and the community (Kline, Brown-Bochicchio, \& Beedle, 2012). An online craft registry would eventually be developed to match craft artists with would-be buyers, but the mainstay of purchases would come from tourists visiting the Appalachian Mountains of North Carolina, HandMade's region. To support craft and craft heritage conservation, HandMade provided a 
number of programmes related to business and entrepreneurship education, community and economic development, and marketing of craft experiences. Their mission is "to grow economies through craft and creative placemaking" (HandMade in America, n.d.). It is estimated that the craft industry provided an economic impact of \$206 million in 2007 (a 69\% increase over the impact noted in 1995 when HandMade started).

Since its inception, HandMade in America has grown to incorporate the additional development of business skills "boot camps", partnerships with schools to integrate craft into K-12 curricula, entrepreneur support networks, residential showplaces for craft, landfill methane recapture to power kilns and furnaces, a regional series of barn quilts and the small towns revitalization and community development project (Kline et al., 2012). A mainstay of the Small Towns Program is the strategy of "selecting a small, visible, and uncontroversial project as a first community endeavor" and then focusing volunteer efforts on these projects (Kline et al., 2012). A key aspect of their community development programme is the revitalization of each community's built environment. In particular, The Bakersville's Creek Walk, Crossnore's stone curbs (and landscaping), and Chimney's Rock's river access found funding through assistance from the Small Towns Program.

\section{Natural disaster}

The 2004 hurricane season went down in history as one of the most damaging natural disaster periods in the USA. Two major hurricanes hit the South Atlantic coast of the USA during the late summer of 2004. Hurricane Francis, the first of these storms, raised mayhem in the Appalachian region of North Carolina, causing severe flooding, structural damage and killing 49 people. It was estimated that over 23 inches of rain fell resulting in $\$ 55$ million in crop damages just in Western North Carolina. President Bush declared a state of emergency in 34 North Carolina counties, allotting \$6.5 million in disaster aid. Ten days later, Hurricane Ivan brought rivers well above their flood plains, causing extensive tornados and numerous mud slides to the region. The General Assembly for the State of North Carolina (2005, p. 1) concluded "that Hurricanes Frances and Ivan wrought havoc upon Western North Carolina impacting the region on a scale not experienced before in that area of the State".

\section{The research sites}

Many of the affected communities had already been involved in the HandMade's Small Town Program. The strategic planning inherent to the programme helped revitalize these communities after the 2004 natural disasters. For this study, three communities were chosen, Bakersville (Mitchell County), Chimney Rock (Rutherford County), and Crossnore (Avery County) to assess the effect that participation in HandMade had on recovery efforts.

Prior to the 2004 hurricane season, Bakersville had already begun a detailed planning process geared towards revitalizing the downtown area. With the help of HandMade in America, a planning document known as the "Bakersville Cookbook" became the foundation for future renovation including the Creek Walk, the re-use of abandoned buildings for art displays and the renovation of the historic downtown courthouse.

Following the flood of 2004, Crossnore received $\$ 90,000$ in assistance from the Federal Emergency Management Agency and from the State of North Carolina. Using connections with HandMade in America, several restoration projects were initiated with this funding, including improvements to the town fountain, bridge, addition of stone curbs and improved drainage, and the refurbishment of the Crossnore Meeting House. 
In the mid-1990s, there were several engaged community groups in Chimney Rock working to improve the quality of life for residents and the economic opportunities for businesses. The partnership between HandMade in America and what would become the Chimney Rock Community Development Association resulted in a number of significant impacts to the town. The eventual development of the river walk, a river park, and a river clean-up effort has provided increased river access for residents and added significantly to the town's tourism product.

\section{Methodology}

The project involved a qualitative process that documented the ripple effects of impacts from HandMade's programmes and Small Town Community development programmes and categorized the impacts into a resilience framework. The data collection was conducted in three phases: 12 in-person interviews with HandMade staff to develop a sense of the organization's beginnings and growth; a review of HandMade news archives, publications, cookbooks, and reports to assess the operational philosophy of the organization; and 3 focus groups, 10 individual interviews, and 3 paired interviews conducted in Bakersville, Crossnore, and Chimney Rock (38 participants total). The data collection process was conducted in 2010 and the data were coded using content analysis and the Smart Draw Program.

\section{Results}

Five themes were derived from the data to include: visioning, planning, and charrettes; Clean, Green, and Screen; grant assistance cycles; cluster meetings; and festivals and special events. Each of these topics will be introduced separately.

\section{Visioning, planning, and charrettes}

One key element of HandMade's approach was that anyone in the community was allowed to participate and have input in the initiative. This support prompted the local community development volunteers to form an organization and apply for 501c3 non-profit status, which then made the towns eligible to receive grants. HandMade assisted with the development plans, designs and "cookbooks" for long-term strategies that provided a process for focusing and organizing future community and economic development activities. HandMade generated publicity about the programmes, which inspired additional buy-in from residents and raised awareness within the community about the rich local assets at hand - assets that could be enhanced to appeal to tourists. The result was the instillation of hope, confidence, energy, and a sense that someone cared. The residents of Bakersville, Chimney Rock, and Crossnore credit the process of visioning the community's future, planning for downtown revitalization, providing input into a charrettes process and the community approach adopted by HandMade for the programme's longevity and success.

\section{Clean, Green, and Screen}

A premise of the Small Towns Program is the strategy of selecting a small, visible, and uncontroversial project as a first community endeavour. The term "Clean, Green and Screen" was applied to these projects to reflect the types of activities that are easy to do and result in a noticeable aesthetic outcome. These projects instilled confidence, prompted the motivation for additional projects and encouraged others to get excited about community development initiatives. The result was the bonding of community members 
and organizations which expanded the volunteer base. New infrastructure brought new uses and new community events, which in turned spurred tourism, expanded local businesses and attracted additional grant funding.

\section{Grant assistance cycles}

HandMade provided five essential elements to support the grant acquisition process: technical assistance on writing proposals, guidance on appropriate funders for projects, letters of support, a feeling of confidence in the abilities and ideas of the community and a network of associations, including HandMade, with which to partner. With the completion of a project, patterns became apparent, such as increased community bonding, community and individual pride, and confidence, and tangible community enhancements, which in turn stimulated a new sense of empowerment and an eagerness for the next project cycle. Some of the grants related to the built infrastructure of the downtown, while others resulted in financial assistance for tourism marketing.

\section{Cluster meetings}

The informants in the study praised the concept of cluster meetings, an annual gathering of the participating small towns. During these meetings, projects were presented, challenges discussed and advice distilled by other communities who had faced similar situations. Respondents commended the process and noted reaping spiritual, psychological, social, and logistical benefits from the annual meeting. Through the sharing of knowledge between communities across the region, participants gained interest in other projects, learned to avoid common pitfalls, found new funding sources and expanded their networks through the camaraderie and peer-support that developed. Successes were felt as shared accomplishments, resulting in a regional spirit and an increased interest in neighbouring projects and people. Because tourism is regional by nature, the increased camaraderie encouraged cross-marketing of the towns.

\section{Festivals and special events}

Festivals and special events were another theme that developed into extended topical discussion in the focus groups and interviews. Participants felt that festivals were a physical celebration of the sense of community that had resulted from their hard work. The festivals encouraged residents to meet new people, inspired communication and belonging, and strengthened community identity. By bringing "outer" county residents as well as tourists into the town, it provided the potential for new revenue streams into the community and revitalized the town centres.

\section{Discussion}

Western North Carolina has a number of natural attractions that draw tourists to the area. However, capturing the tourism spending in the area, especially in many of the rural areas and small towns, requires a strategic approach to tourism development and is vital in the economic recovery after a natural disaster. This paper argues that the development of community resilience helped Bakersville, Chimney Rock, and Crossnore weather in the 2004 hurricane season and resulted in an increase in tourist numbers and spending around the local area. In particular, the facilitation of natural, human, cultural, social, financial, built, and political capital by the HandMade programme allowed these three 
communities the opportunity to expand their tourism base which in turn spurred economic recovery.

The Small Town Program simultaneously focuses on processes (Brown \& Kulig, 1997) and outcomes (Cutter et al., 2008). While keeping resident attention on a tangible result, such as the Clean, Green, and Screen Program or a community festival, the principles of partnering, inclusion and self-efficacy flourished. As noted by Matthews and Selman (2006), communities were better able to utilize their resources, talents, and strengths to create "virtuous circles" and adopt strategies that complement their particular environments (Cutter et al., 2008). Residents leveraged their natural, social, human, and cultural capital to create adaptation strategies (Pfefferbaum, Reissman, Pfefferbaum, Klomp, \& Gurwitch, 2007; Waller, 2001) that allowed them to adjust to disasters, and focus on reconstruction to take advantage of their tourism sectors.

Unlike Calgaro and Lloyd's (2008) conclusion, these towns were able to increase the diversification of the tourism product and support small-scale, local business development, including but not exclusively in the area of local craft. The visioning, grants writing and repetition of Clean, Green, and Screen Projects allowed the community members to grow their capacity, both individually and collectively, over time and gave them access to financial capital (Sherrieb, Norris, \& Galea, 2010) and resulted in a "positive trajectory of functioning and adaptation after a disturbance" (Norris et al., 2008, p. 130). As Maroudas et al. (2004) discuss, the existence of social capital between the local businesses, artisans, community members and nongovernmental agencies provided an avenue for endogenous growth after a series of natural disasters. Through the assessment of the Small Town Program, Table 2 readdresses Magis' (2010) eight community resiliency dimensions as they relate to these communities.

Community and economic development programmes such as HandMade's Small Town Program are not always unanimously supported and are wrought with inherent trials, often specific to the cultural context of the community. Divisions of ethnicity, income level, residential tenure and political position continue to be struggles in any community, but are magnified in rural areas. The continued ability to reach out, welcome and involve new members in a meaningful way in the planning and leadership of the public is a constant challenge in any community. Sometimes the danger of these effective community development efforts is that they become "well-oiled machines" to the point of becoming a closed system. True resiliency would be born from a continuous open system, in which decision-making processes and leadership roles are available to newcomers to the town and newcomers to the process.

In agreement with Shava et al. (2010), the widening of social ties to neighbouring communities has continued to increase community resiliency through the encouragement of traditional values and the infusion of new knowledge. As for the preparation of youth to have developed work habits and a sense of civic involvement, some of this is happening; however, the towns' residents are ageing, and there simply are not that many youth. A more applicable concern might be to what extent the younger generations moving into the community are prepared to become involved in civic matters. This will be the greatest challenge to these small rural towns.

\section{Conclusion and implications}

This paper has discussed a new theoretical approach to understanding the sustainability of communities by presenting the resiliency of three North Carolina towns in their response to a series of devastating hurricanes. Through the HandMade in America programme, 
Table 2. The eight community resilience dimensions as applied to Western North Carolina.

\begin{tabular}{|c|c|}
\hline Dimensions & Associated metrics \\
\hline $\begin{array}{l}\text { Utilization of community } \\
\text { resources }\end{array}$ & $\begin{array}{l}\text { (1) Community leaders increased their networks and were better } \\
\text { able to utilize resources outside the community } \\
\text { (2) The improvements in the built environment provided new } \\
\text { avenues to develop cultural, social, and financial capitals into } \\
\text { tourism products } \\
\text { (3) Financial and political capital were increased through the } \\
\text { generation of new tax revenue and enhanced tourism offerings }\end{array}$ \\
\hline $\begin{array}{l}\text { Development of community } \\
\text { resources }\end{array}$ & $\begin{array}{l}\text { (1) Through access to new revenue ideas and grant writing skills, } \\
\text { community members gained efficacy and learned new ways } \\
\text { incorporating their assets into their tourism offerings } \\
\text { (2) The facilitation of volunteerism gave people an active role in } \\
\text { adapting to change and creating tourism products }\end{array}$ \\
\hline $\begin{array}{l}\text { Engagement of community } \\
\text { resources }\end{array}$ & $\begin{array}{l}\text { (1) The civic leaders in these communities generated novel ideas to } \\
\text { address change and learned to recombine resources in creative } \\
\text { ways } \\
\text { (2) Community members learned to take action in the face of } \\
\text { change rather than being victims of their natural environment }\end{array}$ \\
\hline Active agents & $\begin{array}{l}\text { (1) The Sustainable Tourism Partnership communities have } \\
\text { developed a strong sense of self-reliance in addressing major } \\
\text { issues and changes affecting the community } \\
\text { (2) Increased networking has built social capital throughout the } \\
\text { region, encouraging collaboration and cross-marketing }\end{array}$ \\
\hline Collective action & $\begin{array}{l}\text { (1) Community members are well networked and know how to } \\
\text { look outside the community to find resources to support its } \\
\text { endeavours } \\
\text { (2) Increased confidence and knowledge exchange has encouraged } \\
\text { new ideas along with access to funding sources to ensure } \\
\text { successful implementation }\end{array}$ \\
\hline Strategic action & $\begin{array}{l}\text { (1) Short-term and long-term planning documents are used to guide } \\
\text { future tourism development initiatives }\end{array}$ \\
\hline Equity & $\begin{array}{l}\text { (1) Various groups of the community have access to and utilize the } \\
\text { community's natural and cultural resources } \\
\text { (2) Various groups are actively involved in the decision-making } \\
\text { processes }\end{array}$ \\
\hline Impact & $\begin{array}{l}\text { (1) Each of the towns demonstrated a positive development of their } \\
\text { resources over time } \\
\text { (2) Increased leisure activities, such as festivals and improved } \\
\text { facilities, provide concrete tourism development results }\end{array}$ \\
\hline
\end{tabular}

community resilience was instilled prior to the natural disasters and helped to support the economic and social recovery efforts in Bakersville, Chimney Rock, and Crossnore. With tourists to the mountain region spending approximately $18 \%$ more in these areas compared with the rest of the state (NC Department of Commerce, 2011a, 2011b), it is argued that community revitalization projects had a direct impact on the accumulation of natural, human, cultural, social, financial, built, and political capital. Future research directions should include the development of instruments to appraise a community's progress on these metrics as a means to measure a community's strengths and weaknesses in achieving resiliency. Furthermore, as the Small Town Program has grown, it would be interesting to assess whether other communities have had similar successes after traumatic events. As this study was particularly geared towards recovery after a natural disaster, the measure 
of resilience after other stresses, such as the recent economic downturn, may produce different results.

This study ascertained the presence of community resilience within three Western North Carolina small towns and explored which processes encouraged community resiliency. In particular, the use of charrettes and cluster meetings allowed new ideas to permeate the development process, avoiding what Atterton (2007) describes as "extralocal weak ties" (p. 240). The use of special events to celebrate Appalachian culture and art also brought the residents of the region together in new and expanded ways. Lastly, the insight to keep project small and manageable and the support with grant funding ensured that each new initiative was built on the success of previous projects and embraced each community's resources, talents, and strengths (Ahmed et al., 2004).

These case studies have shown that community resilience is not only a strategy to facilitate recovery after a traumatic event, but can be used as a preventative measure to ensure that a physical trauma does not result in the melt down of an economic, social, and environmental system. While this paper recognizes that community resilience is complex, dynamic, and context dependent (Saxena et al., 2007), this paper shows how resiliency can contribute positively towards sustainable tourism development in changing environments. It also provides a new perspective on the facilitation of community networks prior to a traumatic event and documents the application of community-based project enhancement which allowed these towns to rely on increases in tourism as part of their recovery strategy. As Ahmed et al. (2004) have shown, resilience is not about controlling conditions but developing a community's ability to respond to change. In agreement with Magis (2010), the communities in the HandMade Small Towns Program developed and engaged a range of community resources to thrive in an environment characterized by change, uncertainty, unpredictability, and surprise.

\section{References}

Ahmed, R., Seedat, M., Van Niekerk, A., \& Bulbulia, S. (2004). Discerning community resilience in disadvantaged communities in the context of violence and injury prevention. South African Journal of Psychology, 34, 386-408.

Appalachian Regional Commission. (2010). Moving Appalachia forward: Appalachian regional commission strategic plan 2011-2016. Retrieved from http://www.arc.gov/images/newsroom/ publications/sp/ARCStrategicPlan2011-2016.pdf

Atterton, J. (2007). The strength of weak ties: Social networking by business owners in the highlands and islands of Scotland. Sociologia Ruralis, 47, 228-245.

Boss, P. (2001). Family stress management. Newbury Park, CA: Sage.

Brown, D., \& Kulig, J. (1997). The concepts of resiliency: Theoretical lessons from community research. Health and Canadian Society, 4, 29-52.

Calgaro, E., \& Lloyd, K. (2008). Sun, sea, sand and tsunami: Examining disaster vulnerability in the tourism community of Khao Lak, Thailand. Singapore Journal of Tropical Geography, 29, 288-306.

Chaskin, R. J. (2008). Resilience, community, and resilient communities: Conditioning contexts and collective action. Child Care in Practice, 14, 65-74.

Church, A. (2004). Local and regional tourism policy and power. In A. Lew, C. M. Hall, \& A. M. Williams (Eds.), A companion to tourism (pp. 555-568). Malden, MA: Blackwell.

Coghlan, A., \& Prideaux, B. (2009). A destination-based approach to comparing reef tourism destinations: The case of Australia's Great Barrier Reef and the Caribbean. In R. Dowling \& C. Pforr (Eds.), Coastal tourism development (pp. 237-250). New York, NY: Cognizant Communication Corporation.

Cottrell, L. D. (1976). The competent community. In B. H. Kaplan, R. N. Wilson, \& A. H. Leighton (Eds.), Further explorations in social psychiatry. New York, NY: Basic Books. 
Cutter, S. L., Barnes, L., Berry, M., Burton, C., Evans, E., Tate, E., \& Webb, J. (2008). A place-based model for understanding community resilience to natural disasters. Global Environmental Change, 18, 598-606.

Elsass, P. (1992). Strategies for survival: The psychology of cultural resilience in ethnic minorities. New York: New York University Press.

General Assembly of North Carolina. (2005). Session law 2005-1, Senate Bill 7. Retrieved from http://www.ncleg.net/EnactedLegislation/SessionLaws/PDF/2005-2006/SL2005-1.pdf

Goss, J., \& Burch, D. (2001). From agricultural modernisation to agri-food globalisation: The waning of national development in Thailand. Third World Quarterly, 22, 969-986.

Gunderson, L. H. (2000). Ecological resilience: In theory and application. Annual Review of Ecology and Systematics, 31, 425-439.

HandMade in America. (n.d.). About us. Retrieved from http://www.handmadeinamerica.org/about. html

Hanzah, A., \& Hampton, M. (2013). Resilience and non-linear change in island tourism. Tourism Geographies, 15, 43-67.

Henderson, J., \& Smith, R. A. (2009). Informal tourism commerce at beach resorts: A comparison of Cha-Am and Laguna Phuket in Thailand. Tourism Recreation Research, 34, 13-22.

Kelly, E. C., \& Bliss, J. (2009). Healthy forests, healthy communities: An emerging paradigm for natural resource-dependent communities? Society and Natural Resources, 22, 519-537.

Kline, C., Brown-Bochicchio, C., \& Beedle, J. (2012). A report on the impacts of the Bakersville improvement group and HandMade in America. Greenville, NC: Recreation and Leisure Studies/Center for Sustainable Tourism, East Carolina University.

Lambert, E., Hunter, C. J., Pierce, G. J., \& MacLeod, C. (2010). Sustainable whale-watching tourism and climate change: Towards a framework of resilience. Journal of Sustainable Tourism, 18, 409-427.

Landau, J. (2007). Enhancing resilience: Families and communities as agents for change. Family Process, 46, 351-365.

Lyson, T. (2004). Civic agriculture: Reconnecting farm, food and community. Medford, MA: Tufts University Press.

Magis, K. (2010). Community resilience: An indicator of social sustainability. Society and Natural Resources, 23, 401-416.

Maroudas, L., Kyriakaki, A., \& Gouvis, D. (2004). A community approach to mountain adventure tourism development. Anatolia: An International Journal of Tourism and Hospitality Research, $15,5-18$.

Matthews, R., \& Selman, P. (2006). Landscape as a focus for integrating human and environmental processes. Journal of Agricultural Economics, 57, 199-212.

Norris, F., Stevens, S., Pfefferbaum, B., Wyche, K., \& Pfefferbaum, R. (2008). Community resilience as a metaphor, theory, set of capacities, and strategy for disaster readiness. American Journal of Community Psychology, 41, 127-150.

North Carolina Department of Commerce. (2011a). Direct impact of visitor spend in North Carolina/ county level statistics. Retrieved from http://www.nccommerce.com/tourism/research/ economic-impact/teim

North Carolina Department of Commerce. (2011b). 2011 North Carolina regional travel summary. Retrieved from http://www.nccommerce.com/Portals/8/Documents/Research/Visitation/2011\% 20North\%20Carolina\%20Regional\%20Travel\%20Summary.pdf

Pearce, D. (2001). Tourism. Asian Pacific Viewpoint, 42, 75-84.

Pfefferbaum, B. J., Reissman, D. B., Pfefferbaum, R. L., Klomp, R. W., \& Gurwitch, R. H. (2007). Building resilience to mass trauma events. In L. S. Doll, S. E. Bonzo, J. A. Mercy, \& D. A. Sleet (Eds.), Handbook on injury and violence prevention (pp. 347-358). New York, NY: Springer.

Piorr, H. P. (2003). Environmental policy, agri-environmental indicators and landscape indicators. Agriculture Ecosystems and Environment, 98, 17-33.

Pretty, J. N. (2002). Agri-culture: Reconnecting people, land and nature. Sterling, VA: Earthscan Publications Limited.

Rigg, J. (2006). Land, farming, livelihoods, and poverty: Rethinking the links in the rural South. World Development, 34, 180-202.

Saxena, G., Clark, G., Oliver, T., \& Ilbery, B. (2007). Conceptualizing integrated rural tourism. Tourism Geographies, 9, 347-370. 
Scheyvens, R., \& Momsen, J. (2008). Tourism in small island states: From vulnerability to strengths. Journal of Sustainable Tourism, 16, 491-520.

Shava, S., Krasny, M. E., Tidball, K. G., \& Zazu, C. (2010). Agricultural knowledge in urban and resettled communities: Applications to social-ecological resilience and environmental education. Environmental Education Research, 16, 575-589.

Sherrieb, K., Norris, F. H., \& Galea, S. (2010). Measuring capacities for community resilience. Social Indices Research, 99, 227-247.

Sonn, C., \& Fisher, A. (1998). Sense of community: Community resilient responses to oppression and change. Journal of Community Psychology, 26, 457-472.

Turton, S. M. (2005). Managing environmental impacts of recreation and tourism in rainforests at the wet tropics of Queensland World Heritage area. Geographical Research, 43, 140-151.

Tyrrell, T., \& Johnston, R. (2007). Tourism sustainability, resiliency and dynamics: Towards a more comprehensive perspective. Tourism and Hospitality Research, 8, 14-24.

Varghese, J., Krogman, N. T., Beckley, T. M., \& Nadeau, S. (2006). Critical analysis of the relationship between local ownership and community resiliency. Rural Sociology, 71, 505-527.

Waller, M. A. (2001). Resilience in ecosystemic context: Evolution of a concept. American Journal of Orthopsychiatry, 71, 290-297.

Wilson, G. (2010). Multifunctional 'quality' and rural community resilience. Transactions of the Institute of British Geographers, 35, 364-381.

Zeng, B., Carter, R., \& De Lacy, T. (2005). Short-term perturbations and tourism effects: The case of SARS in China. Current Issues in Tourism, 8, 306-317. 